INDEPENDENT JOURNAL OF MANAGEMENT \& PRODUCTION (IJM\&P)

http://www.ijmp.jor.br

v. 12, n. 5, July-August 2021

ISSN: 2236-269X

DOI: 10.14807/ijmp.v12i5.1413

\title{
STUDY OF SEGMENTATION FOR THE USERS OF PERSONAL CARE PRODUCTS
}

\author{
Archana Y. Lahoti \\ Savitribai Phule Pune University, India \\ E-mail: lahoti_archana2006@yahoo.com
}

Dhiraj Jain

Symbiosis International University, India

E-mail:dhiraj.jain@scmspune.ac.in

Submission: 8/12/2020

Revision: $9 / 9 / 2020$

Accept: 9/23/2020

\section{ABSTRACT}

Person care products (PCP) occupies a major chunk of the market thus making it a largest consumer sector in India. Today due to the media influence, the consumers consider personal care products as a symbol of their life quality and self-image. The objective of this research is to study demographic profile of consumers in the field of personal care products and further segment them on the basis of their buying motive and product preference. A survey of 706 respondents was conducted with structured questionnaire. The questionnaire had demographic questions along with some specific questions to study and segment the consumer group of personal care products. The data was analysed using descriptive statistics and Clustering Analysis using SPSS V20. Clustering Method is used to study group of respondents based on different set of variables. The results of Clustering analysis reveal that marketing mix motives such as product, price, buying convenience, promotional offers and the buying and consumer value motives like quality, brand name, packaging, credibility, natural ingredients and past product experience, plays a vital role while purchasing Personal Care Products.

Keywords: Segmentation; Descriptive research design; Non probability judgmental sampling; Structured questionnaire; Marketing mix motives 
DOI: 10.14807/ijmp.v12i5.1413

\section{INTRODUCTION}

Personal care product's market is generally driven by self-motivation of the consumers. It was observed that, despite demonetization and economic turbulence, this market segment managed to grow annually at a rate of 15-20\% in 2016. Demand for herbal, natural \& organic products, awareness of personal hygiene and importance of personal grooming, and innovative new products as per client requirements were the basic factors that helped the industry to experiment with new products thus satisfying the consumers requirement (Euromonitor, 2016).

Identification, anticipation and satisfaction of client requirement are the fundamental function of marketing. Emerging markets introduce opportunities for businesses to increase market share and profit with a significant outcome. However, to be successful, these companies need effective segmentation. Process of segmentation requires dividing a population into mutually exhaustive sub-groups that are heterogeneous as per a specific criterion.

From the perspective of marketing, identifying those segments and apply targeted marketing tactics can assure profitably. Division of market into different customer groups based on psychographic profile, demographic characteristics, behavioral characteristics and geographical characteristics is called segmentation and it is very crucial stage for the marketer to study segmentation to effectively design strategies with optimal cost.

One of the most challenging and important tasks in marketing is to understand necessity and interest of the client. In this competitive age, customer is the king and to satisfy consumer needs is the fundamental task of the marketer. Studying client profile, analyzing purchase pattern, identifying product demand, and suggesting perfect match products is the prime way of success. Thus, study of business analytics to get insights of consumer behavior is an inseparable part of marketing.

Generally, the researchers conduct cluster analysis which divides the consumer groups, in similar clusters. Clustering is based on segmentation and for this study cluster analysis set of consumers are divided based on their buying motives. Segmentation provides opportunities for marketer to identify underlying dimensions of consumers. Segmentation help to investigate consumers which can be grouped into distinct segments. It helps in knowing the individual client needs, interests and preferences and provide meaningful insight for making correct decisions about user profiles. It also gives insights on buying pattern of consumers in the market.

Consumers have different motives while buying personal care products. The changing 
DOI: 10.14807/ijmp.v12i5.1413

lifestyle of Indian consumers make it imperative for marketers to understand pattern of consumption. Different types of motives influence users of personal care products to buy products. Motives affect outcome such as preference and choice affected by the role of emotions experienced while buying personal care products.

Motives often drive behavior that brings the consumer into the market. Variety of functional motives such as marketing mix motive, functional motive and consumer value motive can influence buyer's buying pattern. Motives can help to understand modern consumer behavior by examining its link. The study considers the underlying motives for consumption choice from evolutionary perspective.

These motives influence behavior, highlighting that many consumer choices functions to help these needs. It helps to bridge the gap between consumer wish and actual buying. Motives are structured in some way around the realities of client's buying experience, rather than being abstract possibilities.

For different categories of products, consumers have different purchase motivation. Predominant shopping motives include convenience, hedonic and practical motives. Beauty products and cosmetics are essential elements of consumer culture especially for women who are keen on their appearance. Physical attractiveness and beauty are emphasized continuously in as admirable and demanding characteristics in today's competitive market.

Store atmosphere, merchandising, assortment of different products, point of purchase displays, convenience, different promotional schemes are significant factors which influence consumer purchasing intentions for beauty and skincare products.

\section{LITERATURE REVIEW}

Ciobanu concluded from their study that the buying reasons and arguments concerning the purchase of a targeted merchandise were related to the co-ordination of activities by both the purchasing company and the company that sold a product after the negotiation is finalized. Psychological, social and demographic factors affect consumer decision process while buying any product. An affluent consumer can take decision more quickly than the middle-income group consumer. The secure consumer can take decision quickly as compare to insecure consumer (Ciobanu, 2014).

Varsha Jain in her study developed a conceptual model that could help marketers of luxury personal care products to develop better strategies. Concern for distinctive looks, peer pressure, impact of different types of media and high disposable income are few reasons for 
DOI: 10.14807/ijmp.v12i5.1413

increasing brand loyalty. Brand value and promise, attractive packaging, quality of the product are few factors which determine the consumer behavior for purchasing personal care products. Social media and country of origin does not have much impact on consumer behavior while purchasing personal care products. These could be valuable insights for marketers to explore new opportunities to cater needs of consumers (Jain, 2014).

Kadam Vaishali explored in her studies that skincare market is the fastest-growing segment in Cosmeceuticals. Many Cosmeceutical treatments such as hyperpigmentation, wrinkles and photoaging include a combination of pharmaceuticals and cosmetics (Vaishali, 2013).

Bassi discovered that market segmentation is a significant technique in marketing to identify different segments. Statistical methods such as cluster segmentation can give different segments some distinct advantages. In clustering methods, Latent class model is prevalent, which is very flexible and innovative and can divide market into different sub segments thereby helping marketers to design and develop effective marketing strategies. Due to constant changes in consumer needs and product choices, marketer has to often search for different market segments. A mixture latent class Markov model can provide dynamic segmentation model for financial product's possession in Italian households. This model can forecast consumer behavior in buying financial products (Bassi, 2014).

Branko R. and Maričić concluded in their study that strategic marketing planning is base for business success and growth. Market segmentation is an essential tool to find preferences of customers as they are heterogeneous in their preferences. Segmentation can be used as essential tool to plan marketing activities in the long term. Empirical research based on customer expectation and preferences can help in market segmentation. Along with traditional segmentation bases, behavioral model is used to find the most effective segmentation method. Result indicated that for performing strategic market analysis, the most important criteria is market segmentation (Maričić, 2015).

Adriana Beatriz Madeira stated that advanced segmentation is the process of identifying customers that are internally identical and concerned to other diverse groups. Segmentation is very important task to make more accurate decisions. The dynamic nature of modern-day consumers has changed the dimensions, importance, customer experiences and has directly impacted the process of segmentation. New concepts and changes in consumer characteristics have changed methods of market segmentation. Study of market segmentation along with other 
INDEPENDENT JOURNAL OF MANAGEMENT \& PRODUCTION (IJM\&P)

http://www.ijmp.jor.br

v. 12, n. 5, July-August 2021

ISSN: 2236-269X

DOI: 10.14807/ijmp.v12i5.1413

branches such as economics, sociology, psychology can assist in designing new market segments (Madeira, 2015).

MarijaCerjak found that various factors such as pricing, packaging, advertising and quality are very influential in deciding buying behavior. Quality is the most critical determinant which influence consumers to buy the products especially for PCP (Cerjak, 2010).

Matea Matić studied factors such as skin health consciousness, self-image, age and ageing factors are the significant determinants for purchasing skincare products among male consumers (Matić, 2016).

Sultan M M found majority of consumers preferring herbal skincare products over traditional products which used chemicals. This is beautiful opportunity for skincare manufacturers to grab this promising market. Values perceived by buyers for herbal PCP and buying motives of millennial in Bangladesh are influenced by 4P's of Marketing, i.e. product, price, place and promotion mix of herbal skincare products (Sultan, 2013).

Tan Chun Eng identified factors such as growing awareness, metrosexual trend and concerns of self-image has created a lucrative market for production of personal grooming, cosmetics and skincare products among male in Malaysia. This has created a niche market for personal care product industry to cater needs of this segment (Eng, 2018).

Otto Regalado Pezúa studied that consumption of PCP and services for the male is increasing all over the world. Non-economic factor such as environmental factors have limited intention to use these products. Marketers need to design marketing program to create awareness for this among buyers (Pezúa, 2016).

Dhrumil Thakkar discovered that demographic factors such as age, gender, income, occupation as well as social, cultural, personal and psychological factors have a huge impact on the purchase of the male grooming factor especially for face wash (Thakkar, 2017).

Dr. Nuntasaree Sukato studied the phenomenon of male consumer behavior for buying SC products, Fishbein and Ajzen's developed reasoned action model. In this theoretical framework author found, beliefs, normative influence, aspirations and perception of self-image have a significant impact on purchasing behavior for skincare products for male patrons in Bangkok. In this theory new construct namely, self-image has been added to explain male consumer behavior for skin care products (Sukato, 2009).

Abdullah Bin Junaid constructed a conceptual model consisting of various factors 
DOI: 10.14807/ijmp.v12i5.1413

associated with purchasing and consuming skincare product has been developed by author, which will be helpful for beauty industries (Junaid, 2013).

Kim (2011) developed theory of planned behavior to examine the effect of past experiences for using organic products and consumer values to study the purchase intention of consumers of personal care products. Attitude for buying organic beauty products is positively related with appearance and environmental consciousness. Retailers of beauty products can implement an effective strategy to emphasize on organic products by implementing effective strategies based on ecological beauty, product safety and reasonable prices (Kim, 2011).

Anandarajan found that consumers are increasingly becoming aware of the harmful effects of chemicals in PCP and are heading towards ayurvedic products (Anandarajan, 2016). One of the studies by Vibhuti investigated that consumer behavior for FMCG products is mostly affected by 4 Ps marketing along with physiological and psychological factors (Vibhuti, 2014). Samar Fatima suggested that advertisements creates awareness in people but fails to build a strong perception in the consumers mind (Fatima, 2015).

Bee Li Yeo explained Theory of Consumption Value (TCV) to explore correlation among customer contentment and perceived value of customers for halal products. The consumption value model consists of functional, social epistemic, emotional and conditional value. According to study brand value can be added as new value dimension to the original model. These dimensions can give better insights for explaining consumers 'choices and reactions (Yeo, 2016).

Victor Hugo found that men and women have different perceptions while buying cosmetics and they are expressing their individuality. Men are more concerned with oiliness whereas females are concerned with oiliness and stickiness.Women buy more skincare products whereas sale of haircare products are same for both genders (Infante, 2016).

KamyarKianpour explored consumer awareness and perception are essential motivators to buy products.The important motivators to buy green products are a concern for the environment, knowledge of consumer, perceived benefits by the consumers, different laws and regulations and promotional efforts taken by retailers to attract green consumers. These are essential determinants to buy green products (Kianpour, 2014).

Ahaiwein his study suggested that brand preferences for cosmetics are influenced by different extrinsic and intrinsic factors such as gender, income, occupation, age, and social class status. Product characteristics such as quality, brand name, packaging, price, shelf life 
INDEPENDENT JOURNAL OF MANAGEMENT \& PRODUCTION (IJM\&P)

http://www.ijmp.jor.br

v. 12, n. 5, July-August 2021

ISSN: 2236-269X

DOI: 10.14807/ijmp.v12i5.1413

and fragrances are essential determinants of brand preferences for beauty products. Also, brand preference for cosmetics is determined by factors such as age, gender, income status, occupation and social class. Thus, demographic factors have a significant impact on buying behavior of customers (Ahaiwe, 2015).

The research study by Caroline SueLinadvised beauty care products companies should study demographic factors to create and retain acceptance of cosmetic products. Conservative Consumer black- box model is unsuccessful in providing an inclusive picture of consumer's mind. Models designed by Engel,Kollat and Blackwell model and Hawkins, Best and Coney model prove that emotions play an important role in decision-making process for buying different types of goods (SueLin, 2010).

Nadai suggested that relatively more spending on beauty product during the recession period is the phenomenon known as Lipstick effect. Psychological motives such as a feeling of happiness in personal life, feeling confident in professional life and a romantic relation have been studied. It has been found that only a romantic relationship is the only driver to buy lipstick for women (Nadai, 2015).

Constantin compared K-means cluster and two-step cluster to find the best method for segmenting the market. Post hoc market segmentation method was used to find segments with specific attitudes or behavior. Findings suggest that both methods have advantages and disadvantages. A researcher can choose between both the methods which can give better analysis of data (Constantin, 2012).

Varsha Jain studied usage of luxury brands particularly in PCP market is escalating in India. People are becoming aware for their external appearances, concern for individual looks, peer pressure, impact of different types of media and high disposable income are few reasons for increasing brand loyalty. Brand value and promise, attractive packaging, quality of the product are few factors which determine the consumer behavior for purchasing personal care products.Social media and country of origin does not have much impact on consumer behavior while purchasing personal care products. These could be important insights for the marketers to explore new opportunities to cater needs of the consumers (Varsha Jain, 2014).

Tan Chun concludes that growing awareness, increased disposable income and concern of self-image has gained the marketers attention to study this lucrative segment to earn profits. Marketers can serve this niche market by exploring new products to cater needs of this segment. Cosmetic companies,skin care companies can design new products to serve this niche market. 
DOI: 10.14807/ijmp.v12i5.1413

The conceptual model was proposed by Tan Chun which can predict consumption behavior of the male consumers for purchasing skincare products. This can be used by personal care products industries to formulate marketing strategies to serve this niche lucrative market (Tan, 2018).

Literature analysis exposed shortcomings such as demographic profile on large-scale survey sample for consumers of personal care items. Previous experiments with limited sample size have been carried out such that findings cannot be generalized. Most experiments were carried out to research the purchasing behavior of personal care goods consumers. There is no segmentation analysis focused on intentions for the purchasing of personal care products.

In view of literature, we believe that segmentation is an essential activity for marketing managers to provide efficient consumer experiences and to obtain competitive advantages in the industry. When the competition is dominated by a vast variety of local, national and foreign goods it is certainly a business challenge to split this massive market into similar segments, so that current customers are maintained and new buyers are drawn. By analyzing numerous motivations and desires of purchasers to use PCP, researchers have established the hypothesis,

- H1: Buying Motives \& Product characteristics changed the focus of segmentation of PCP Users.

\section{METHODOLOGY}

The primary methodology used in this study is exploratory study which was followed by conclusive research. Conventionally marketing research utilizes quantitative approach to give insights for taking marketing decision. (Malhotra, 2004). Quantitative descriptive research explains about describing, recording the data, analyzing and interpretation related to the study. Appropriates statistical tools and techniques are applied to describe the data and answer for the research related queries, meeting the objectives and goals of the research and interpret results of the present study. The findings from the conclusive study can be used as input to make managerial decision making.

\subsection{Sample Collection and Sample Size}

Quota sampling methodology was applied by selecting wards of Pune region. Quota sampling is a non-probability sampling methodology which is a two-stage judgmental sampling. Researcher selected these wards and famous cosmetics stores were selected to collect data from respondents. Customers who were purchasing many cosmetics and ready to 
DOI: 10.14807/ijmp.v12i5.1413

cooperate were selected to gather data. The selection of sample size was based on specified proportion constructed on number of variables in questionnaire.

A structured questionnaire was used as a research instrument to collect information from the consumers. Non probability judgmental sampling method was used to collect sample. A total of 850 questionnaires are distributed personally to the users of personal care products in which 706 valid respondents were obtained (response rate 83\%). This study evaluates the role of demographic variables and its effect of study variables for the present study. Hence the general information of demographic profiles such as gender, age, marital status, education qualification, occupation, monthly income was included for data collection and are presented in below tables.

\subsection{Research Method}

The collected data was properly tabulated and evaluated. Statistical packages such as SPSS V20 are used to carry out the statistical analysis. Cluster analysis is used to Group the similar respondent who uses personal care products. Non-Hierarchical K means Clustering Method was used as statistical method to cluster the samples into different clusters.

\subsection{Cluster Analysis}

Cluster Analysis classifies respondents into a certain group of respondents based on certain variables. It helps to segment customers in different groups. The aim is that members of the particular group share similar characteristics with members of the same group and share heterogeneous characteristics with members of other groups.

The idea of cluster analysis is to divide objects into distinct clusters,to achieve maximum homogeneity of objects within the cluster, and to achieve maximum heterogeneity between the clusters. The study used cluster analysis to divide consumers based on functional motives such as marketing mix motives, buying and consumer value motives for purchasing personal care products.

Based on review of literature, different functional motives were found. Marketing mix motives such as price, the convenience of buying products, attractive packaging, advertisement of personal care products, promotional scheme and celebrity endorsement have a significant impact while purchasing personal care products.

Buying and consumer value motives such as products made of natural resources, innovative products, the credibility of the products, suitability to use, latest trends, previous 
DOI: 10.14807/ijmp.v12i5.1413

experience of using personal care products, branded products, quality products, environment friendly products, importance of personal grooming have a significant impact while purchasing personal care products.

Cluster analysis is used to group observations using a measure of association which are similar to homogenous subgroups, so the samples within the group are similar, and samples are dissimilar in other groups. These subgroups reveal pattern relates to a phenomenon under present study. Cluster analysis is also named as classification analysis, and it belongs to the unsupervised learning technique. The commonly used method to find similarity is Euclidean distance which is the square root of sum of squared differences in value of all variables. Several clustering methods are available, and one decides the procedure based the research problem.

Clustering procedure can be classified into Hierarchical, which is tree-like structure and non-hierarchical clusters. Hierarchical methods can be divided into agglomerative and divisive; Ward's procedure is commonly used to find variance method which is part of agglomerative method. Based on cluster membership and dendogram using Ward method, number of clusters can be determined.

In the present study three groups are identified based on dendogram and cluster membership. The Non-hierarchical method is also called k-means clustering which is classified into sequential \& parallel threshold and optimizing partitioning. (Malhotra \& Dash, 2015). Using k-means clustering, the significance of the clusters areverified, and it is helpful to interpret the profile of the respondents who use personal care products in terms of groups.

\section{RESULTS AND DISCUSSION}

In Logistics subject, the participants of this study have worked on creating a fictional company covering aspects like: name, product, mission, objectives, target, market and so on. Students had also learned topics related to Logistics: distribution channel, supply chain, retail, wholesale and how to measure the company service satisfaction.

\subsection{Demographic Profile of Consumers using Personal Care products}

As per Focus Group analysis results, six products such as Face cream, moisturizer, face wash, Shampoo, Conditioner and Hair Oil which were used by both males and females. The rationale of this study was to understand the range of personal care products used by males and females in the Indian personal care products market.

There are behavioral differences while consumption of personal care products by male 
INDEPENDENT JOURNAL OF MANAGEMENT \& PRODUCTION (IJM\&P)

http://www.ijmp.jor.br

v. 12, n. 5, July-August 2021

ISSN: 2236-269X

DOI: 10.14807/ijmp.v12i5.1413

and female. Criteria for selecting sample were to use at least four products mentioned in personal care products range. The results in Table 1 shows 173 male \& 533 females are using Personal care products thus emphasizing the fact that females give more importance to looks as compare to males.

The age group (22.2\%) were 18-28 years age category, 191 (27.1\%) were 28-38 years age group, 188 (26.6\%) from 38-48 years, 114 (16.1\%) were 48-58 years age group and 56 (7.9\%) from above 58 categories respectively. From the samples 396 (56.1\%) were married, 308 (43.6\%) were unmarried and $2(0.3 \%)$ are from any other category. In terms of educational qualification, 13 (1.8\%) completed SSC, 50 (7.1\%) were from HSC category, 210(29.7\%) from Graduation category, 363(51.4\%) completed post-graduation and 70 (9.9\%) were doctorate category.

The occupation category consists of government job 118 (16.7\%), 199(28.2\%) were from professional job category, 135(19.1\%) were self-employed, 82(11.6\%) were house wife, student's category were 110(15.6\%), other service relates job respondents were 34(4.8\%) and 28(4.0\%) were from any other category. In terms of monthly income, 196(27.8\%) earning 10000-30000 Rs, 207(29.3\%) were earning Rs 30,000 - Rs 50,000 Rs, 144(20.4\%) were Rs 50,000 - Rs 70,000 category and 159(22.5\%) earning more than Rs 70,000.

Table 1: Frequency analysis for Demographic Variables

\begin{tabular}{|l|l|l|}
\hline \multirow{4}{*}{ Gender } & Variable & Frequency \\
\hline \multirow{5}{*}{ Age } & Male & $173(24.5 \%)$ \\
\cline { 2 - 3 } & Female & $533(75.5 \%)$ \\
\hline \multirow{5}{*}{ Marital Status } & $18-28$ & $157(22.2 \%)$ \\
\hline & $28-38$ & $191(27.1 \%)$ \\
\cline { 2 - 3 } & $38-48$ & $188(26.6 \%)$ \\
\hline & $48-58$ & $114(16.1 \%)$ \\
\cline { 2 - 3 } & 58 and above & $56(7.9 \%)$ \\
\hline \multirow{5}{*}{ Oducational Qualification } & Married & $435(61.6 \%)$ \\
\cline { 2 - 3 } & Unmarried & $231(32.7 \%)$ \\
\cline { 2 - 3 } & Any Other & $40(5.7 \%)$ \\
\hline & SSC & $13(1.8 \%)$ \\
\cline { 2 - 3 } & HSC & $50(7.1 \%)$ \\
\cline { 2 - 3 } & Graduate & $210(29.7 \%)$ \\
\cline { 2 - 3 } & Post Graduate & $363(51.4 \%)$ \\
\hline & Doctorate & $70(9.9 \%)$ \\
\cline { 2 - 3 } & Government Job & $118(16.7 \%)$ \\
\cline { 2 - 3 } & Professional Job & $199(28.2 \%)$ \\
\cline { 2 - 3 } & Self Employed & $135(19.1 \%)$ \\
\cline { 2 - 3 } & Housewife & $82(11.6 \%)$ \\
\cline { 2 - 3 } & Student & $110(15.6 \%)$ \\
\cline { 2 - 3 } & Service & $34(4.8 \%)$ \\
\cline { 2 - 3 } & Any Other & $28(4.0 \%)$ \\
\hline \multirow{5}{*}{ Monthly Income } & $10000-30000$ & $196(27.8 \%)$ \\
\cline { 2 - 3 } & $30000-50000$ & $207(29.3 \%)$ \\
\cline { 2 - 3 } & $50000-70000$ & $144(20.4 \%)$ \\
\hline & &
\end{tabular}


DOI: 10.14807/ijmp.v12i5.1413

\begin{tabular}{|l|c|l|} 
& $70000 \&$ above & $159(22.5 \%)$ \\
\hline Total & & $706(100 \%)$ \\
\hline
\end{tabular}

\subsection{DENDOGRAM}

In the present study, Dendogram is used for clustering the respondents who use personal care products. From the results of Dendogram, the present study has classified three clusters. Figure 1 shows the Dendogram.

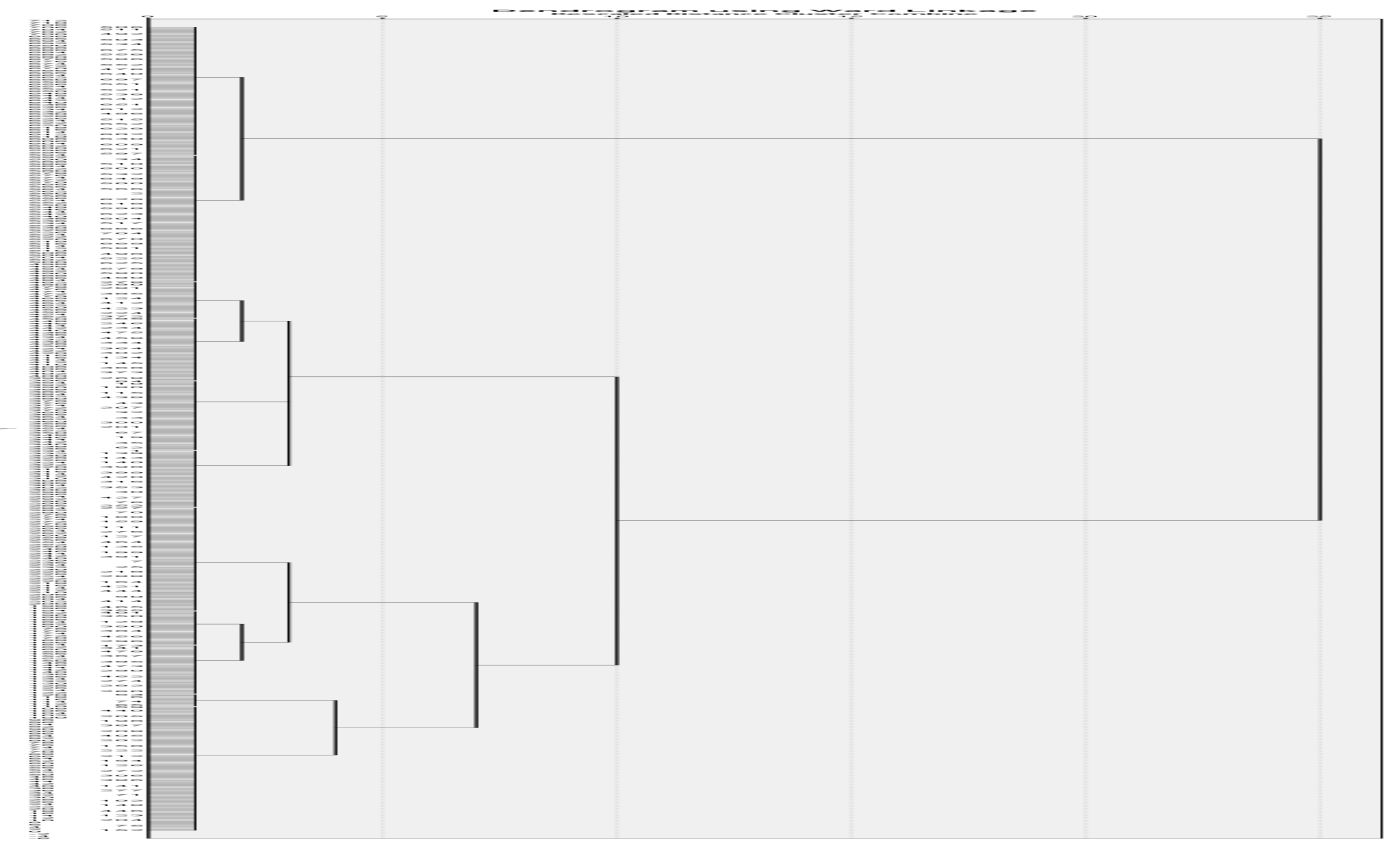

Figure 1: Dendogram for 3 cluster solutions using Wards method

The type of nature of dendogram allows the researcher to proceed forward to backward at any level of individual clusters. This study has identified three clusters so non-hierarchical clustering (k-means clustering) is used as shown in Table 2 to obtain more stable clusters.

Table 2: Results of non-hierarchical clustering (k-means clustering)

\begin{tabular}{|c|c|c|c|c|c|c|}
\hline \multicolumn{7}{|l|}{ ANOVA } \\
\hline & \multicolumn{2}{|l|}{ Cluster } & \multicolumn{2}{|l|}{ Error } & \multirow[b]{2}{*}{$\mathrm{F}$} & \multirow[b]{2}{*}{ Sig. } \\
\hline & Mean Square & $\mathrm{df}$ & Mean Square & $\mathrm{df}$ & & \\
\hline $\begin{array}{l}\text { Preference for Personal care products } \\
\text { which are made up of natural resources }\end{array}$ & 39.513 & 2 & .445 & 703 & 88.887 & .000 \\
\hline Preference Innovative products & 79.437 & 2 & .859 & 703 & 92.530 & .000 \\
\hline $\begin{array}{l}\text { Credibility is very imp while using } \\
\text { Personal care products }\end{array}$ & 43.986 & 2 & .659 & 703 & 66.700 & .000 \\
\hline $\begin{array}{l}\text { Preference of Personal care products } \\
\text { which are suitable to use }\end{array}$ & 37.239 & 2 & .396 & 703 & 93.965 & .000 \\
\hline $\begin{array}{l}\text { Price of Personal care products is not } \\
\text { important }\end{array}$ & 185.110 & 2 & 1.009 & 703 & 183.542 & .000 \\
\hline Preference for Branded Products & 54.886 & 2 & .464 & 703 & 118.309 & .000 \\
\hline Quality is very important & 41.980 & 2 & .335 & 703 & 125.364 & .000 \\
\hline $\begin{array}{l}\text { Preference for reading ingredients of } \\
\text { Personal care products }\end{array}$ & 55.836 & 2 & .722 & 703 & 77.349 & .000 \\
\hline $\begin{array}{l}\text { Convenience of buying product not } \\
\text { important }\end{array}$ & 200.122 & 2 & .811 & 703 & 246.627 & .000 \\
\hline
\end{tabular}


INDEPENDENT JOURNAL OF MANAGEMENT \& PRODUCTION (IJM\&P)

http://www.ijmp.jor.br

v. 12, n. 5, July-August 2021

ISSN: 2236-269X

DOI: 10.14807/ijmp.v12i5.1413

\begin{tabular}{|c|c|c|c|c|c|c|}
\hline $\begin{array}{l}\text { Preference of Personal care products } \\
\text { which are not tested on animals }\end{array}$ & 130.856 & 2 & .838 & 703 & 156.093 & .000 \\
\hline $\begin{array}{l}\begin{array}{l}\text { Preference of latest trend for Personal } \\
\text { care products }\end{array} \\
\end{array}$ & 122.609 & 2 & .966 & 703 & 126.942 & .000 \\
\hline Preference for using domestic products & 233.080 & 2 & 1.234 & 703 & 188.931 & .000 \\
\hline $\begin{array}{l}\text { Previous experience is very important } \\
\text { while using Personal care products }\end{array}$ & 40.377 & 2 & .350 & 703 & 115.448 & .000 \\
\hline $\begin{array}{l}\text { Packaging of Personal care products not } \\
\text { very important }\end{array}$ & 350.718 & 2 & .876 & 703 & 400.458 & .000 \\
\hline $\begin{array}{l}\text { Preference for environment friendly } \\
\text { products }\end{array}$ & 59.410 & 2 & .438 & 703 & 135.589 & .000 \\
\hline $\begin{array}{l}\text { Advertisement of Personal care products } \\
\text { is not very important }\end{array}$ & 273.927 & 2 & .917 & 703 & 298.745 & .000 \\
\hline $\begin{array}{l}\text { Personal Grooming is very important to } \\
\text { maintain image }\end{array}$ & 45.492 & 2 & .582 & 703 & 78.138 & .000 \\
\hline $\begin{array}{l}\text { Preference for using Personal care } \\
\text { products based on previous usage }\end{array}$ & 53.166 & 2 & .321 & 703 & 165.865 & .000 \\
\hline Preference for Promotional schemes & 72.525 & 2 & .988 & 703 & 73.371 & .000 \\
\hline No influenced by Celebrity Endorsement & 227.615 & 2 & 1.058 & 703 & 215.098 & .000 \\
\hline Not influenced by Advertisements & 273.827 & 2 & .993 & 703 & 275.651 & .000 \\
\hline
\end{tabular}

The $\mathrm{F}$ tests should be used only for descriptive purposes because the clusters have been chosen to maximize the differences among cases in different clusters. The observed significance levels are not corrected for this and thus cannot be interpreted as tests of the hypothesis that the cluster means are equal.

The resultsofnon-hierarchical clusteringshowsthat allthe variables aresignificant at1\% levelofsignificance asshowninTable2.Thepresentstudy relatedto personal care products respondentoftotal706classifiesintothree clusters,inthe first clustergroup,there are372 respondents,318 respondentsinsecond cluster andonly 16 respondentsinthethird cluster.

Table 3: Descriptive statistics for Profile of cluster I

\begin{tabular}{|l|c|c|c|}
\hline & N & Mean & Std. Deviation \\
\hline Preference for Personal care products which are made up of natural & 372 & 4.09 & .755 \\
resources & & & \\
\hline Preference Innovative products & 372 & 3.41 & .988 \\
\hline Credibility is very imp while using Personal care products & 372 & 4.19 & .866 \\
\hline Preference of Personal care products which are suitable to use & 372 & 4.30 & .629 \\
\hline Price of Personal care products is not important & 372 & 2.86 & 1.148 \\
\hline Preference for Branded Products & 372 & 4.22 & .764 \\
\hline Quality is very important & 372 & 4.53 & .584 \\
\hline Preference for reading ingredients of Personal care products & 372 & 3.44 & .965 \\
\hline Convenience of buying product not important & 372 & 2.31 & .841 \\
\hline Preference of Personal care products which are not tested on animals & 372 & 2.93 & 1.027 \\
\hline Preference of latest trend for Personal care products & 372 & 3.04 & 1.053 \\
\hline Preference for using domestic products & 372 & 2.66 & 1.201 \\
\hline Previous experience is very important while using Personal care products & 372 & 4.25 & .634 \\
\hline Packaging of Personal care products not very important & 372 & 2.36 & 1.001 \\
\hline Preference for environment friendly products & 372 & 3.85 & .763 \\
\hline Advertisement of Personal care products is not very important & 372 & 2.67 & 1.158 \\
\hline Personal Grooming is very important to maintain image & 372 & 4.06 & .848 \\
\hline Preference for using Personal care products based on previous usage & 372 & 4.26 & .595 \\
\hline Preference for Promotional schemes & 372 & 3.40 & 1.050 \\
\hline No influenced by Celebrity Endorsement & 372 & 2.84 & 1.264 \\
\hline Not influenced by Advertisements & 372 & 2.81 & 1.246 \\
\hline Valid N (listwise) & 372 & & \\
\hline Cluster Number of Case = 1 & & & \\
\hline
\end{tabular}


INDEPENDENT JOURNAL OF MANAGEMENT \& PRODUCTION (IJM\&P)

http://www.ijmp.jor.br

v. 12, n. 5, July-August 2021

ISSN: 2236-269X

DOI: $10.14807 /$ ijmp.v12i5.1413

Table 4: Descriptive statistics for Profile of cluster II

\begin{tabular}{|l|c|c|c|}
\hline & N & Mean & Std. Deviation \\
\hline Preference for Personal care products which are made up of natural resources & 318 & 4.46 & .518 \\
\hline Preference Innovative products & 318 & 4.20 & .838 \\
\hline Credibility is very imp while using Personal care products & 318 & 4.28 & .732 \\
\hline Preference of Personal care products which are suitable to use & 318 & 4.31 & .595 \\
\hline Price of Personal care products is not important & 318 & 4.24 & .817 \\
\hline Preference for Branded Products & 318 & 4.37 & .545 \\
\hline Quality is very important & 318 & 4.44 & .503 \\
\hline Preference for reading ingredients of Personal care products & 318 & 4.12 & .656 \\
\hline Convenience of buying product not important & 318 & 3.81 & .965 \\
\hline Preference of Personal care products which are not tested on animals & 318 & 4.06 & .774 \\
\hline Preference of latest trend for Personal care products & 318 & 4.15 & .882 \\
\hline Preference for using domestic products & 318 & 4.28 & .990 \\
\hline Previous experience is very important while using Personal care products & 318 & 4.36 & .501 \\
\hline Packaging of Personal care products not very important & 318 & 4.35 & .844 \\
\hline Preference for environment friendly products & 318 & 4.39 & .496 \\
\hline Advertisement of Personal care products is not very important & 318 & 4.42 & .648 \\
\hline Personal Grooming is very important to maintain image & 318 & 4.39 & .640 \\
\hline Preference for using Personal care products based on previous usage & 318 & 4.57 & .503 \\
\hline Preference for Promotional schemes & 318 & 4.14 & .921 \\
\hline No influenced by Celebrity Endorsement & 318 & 4.43 & .659 \\
\hline Not influenced by Advertisements & 318 & 4.52 & .587 \\
\hline Valid N (listwise) & 318 & & \\
\hline Cluster Number of Case = 2 & & & \\
\hline
\end{tabular}

Table 5: Descriptive statistics for Profile of cluster III

\begin{tabular}{|l|c|c|c|}
\hline & $\mathbf{N}$ & Mean & Std. Deviation \\
\hline Preference for Personal care products which are made up of natural resources & 16 & 2.38 & 1.025 \\
\hline Preference Innovative products & 16 & 1.94 & 1.124 \\
\hline Credibility is very imp while using Personal care products & 16 & 1.87 & 1.025 \\
\hline Preference of Personal care products which are suitable to use & 16 & 2.13 & 1.147 \\
\hline Price of Personal care products is not important & 16 & 1.81 & .750 \\
\hline Preference for Branded Products & 16 & 1.69 & 1.014 \\
\hline Quality is very important & 16 & 2.19 & 1.377 \\
\hline Preference for reading ingredients of Personal care products & 16 & 2.31 & 1.302 \\
\hline Convenience of buying product not important & 16 & 1.94 & .929 \\
\hline Preference of Personal care products which are not tested on animals & 16 & 1.81 & .750 \\
\hline Preference of latest trend for Personal care products & 16 & 2.06 & 1.181 \\
\hline Preference for using domestic products & 16 & 2.38 & 1.204 \\
\hline Previous experience is very important while using Personal care products & 16 & 2.06 & 1.063 \\
\hline Packaging of Personal care products not very important & 16 & 2.00 & 1.095 \\
\hline Preference for environment friendly products & 16 & 2.00 & .966 \\
\hline Advertisement of Personal care products is not very important & 16 & 2.13 & .957 \\
\hline Personal Grooming is very important to maintain image & 16 & 2.06 & .929 \\
\hline Preference for using Personal care products based on previous usage & 16 & 2.00 & .966 \\
\hline Preference for Promotional schemes & 16 & 1.94 & 1.063 \\
\hline No influenced by Celebrity Endorsement & 16 & 2.38 & .957 \\
\hline Not influenced by Advertisements & 16 & 1.94 & .929 \\
\hline Valid N (listwise) & 16 & & \\
\hline Cluster Number of Case = 3 & & & \\
\hline
\end{tabular}

Based on clusters data analysis, the results show that:

- Cluster I resultas shown in Table 3 has relatively high values for the variables such as quality is very important to them. The participants used personal care products which 
were suitable to use, preferred using Personal care products based on previous usage and previous experience which made these attributes very important tothem while buying personal care products. Hence, cluster I can be labelled as “Quality conscious” shoppers.

- Cluster II results as shown in Table 4 has high values for the variables such as using personal care products based on previous usage, preferring products which are made up of natural resources, preferred quality personal care products, preferred environment friendly products, products that maintain images so personal grooming products, some preferredbranded products, some preferred by analyzing previous experience while using personal care products. Hence, this cluster II had many preferences and thereby can be classified as "Branded and innovative shoppers with more preferences".

- Cluster III results as shown in Table 5 is just opposite to cluster II with low values on variables such as price of personal care products is not important for them. They preferredpersonal care products which are not tested on animals, and convenience of buying product is not that important for them. It was also seen that they did not get influenced by advertisements, packaging of products either. Hence, advertisement of personal care products is not very important for them. And looking at these preferences, final cluster III can be named as “unconcerned shoppers”.

\section{CONCLUSION}

Customers are very keen on using personal care products for grooming themselves and protect their self-image. Usage of personal care products has increased among all the age groups irrespective of age, gender, educational qualification, occupation and marital status especially in urban consumers. Motives play very vital role to influence consumers to buy different types of personal care products.

Age, occupation, educational qualification, gender \& usage of personal care products are important determinants to buy personal care products. One can conclude that females are using range of personal care products as compared to male. Occupation and usage of PCP are also strongly related. Person with professional jobs are more concerned for their external appearances as compare to others. Age is very important factor in determining usage of personal care products.

People in the age group of 18- 28 , 28-38, 38-48 tend to use more no of personal care products as compare to age group of 48 and above Educational qualification, occupation and 
INDEPENDENT JOURNAL OF MANAGEMENT \& PRODUCTION (IJM\&P)

http://www.ijmp.jor.br

v. 12, n. 5, July-August 2021

ISSN: 2236-269X

DOI: 10.14807/ijmp.v12i5.1413

usage of personal products range is also very significant indicating people with better education gives more important for grooming as compare to less educational qualification.

Income and usage of personal care products are strongly related indicating person with more disposable income will buy and indulge in different range of personal care products. Person with high income group are purchasing different types of personal care products to groom themselves as compare to people with low income group. People with high income group are ready to spend more money on grooming.

Review of literature and focus group interviews revealed different functional and value motives such as quality, brand name, price, convenience of buying, distinguished image in society, natural ingredients, chemical free products, herbal products are important determinants to buy PCP.While analyzing the data it is found that consumers are more inclined towards using personal care products for self-presentation, self- esteem and distinguished image between professional fields.

Gender, age, educational qualification, occupation, income have significant impact on buying motives for personal care products. Marital status does not have any influence on buying motive of users of personal care products.

Different segments give diverse view of market thus providing important insight for expanding business by offering competitive advantage to consumers. Segmentation helps in providing distinct segments without overlooking subtle differences. The research studies marketing mix motives and customer value motives such as quality products, brand name, previous experience to use personal care products, sales promotional scheme, packaging, celebrity endorsement, usage natural ingredients etc. which are important motives to buy personal care products.

Hence, hierarchical clustering segmentation method was used to divide the sample of 706 respondents into different clusters. K means clustering have identified 3 clusters for these respondents. Based on this three clusters such as "Quality conscious shoppers”, "branded and innovative shoppers with more preferences" and "unconcerned shoppers” have been found. Segmentation can help marketers to effectively subgroup the customers and target customers more efficiently. Out of 706 respondents, 372 peoplewere found in cluster I.

This cluster results provides very important insight to marketing Manager for beauty care products that quality is the most important determinant to buy these category products. Out of 706, 318 respondents were found in this cluster II. From this cluster results it was found 
DOI: 10.14807/ijmp.v12i5.1413

that consumers personal grooming is very important because they were very keen to maintain their image in society. Out of 706, only 16 respondents were present in the last cluster III.The results of this cluster indicated consumers gave least importance to advertisement or packaging of the product while buying the products.

The study thus reflects different motives and the buying intensions of consumers depending on the characteristics of the products. Thus, the given hypothesis "Buying Motives \& Product characteristics changed the focus of segmentation of PCP Users” is accepted and proved.

One can thus conclude that people are very conscious of their self-image and external appearance and they give ample importance to buying such personal care products. Very few out of the selected sample were unconcerned shoppers. Thus, personal care products buyers are quality conscious and prefer branded and innovative products.

\subsection{Applicability \& Generalizability:}

Cluster analysis is helpful to segment consumers based on their profile and motives to buy personal care products. Segmentation is vital strategy for the marketers to divide consumers based on their preferences. Distinct clusters can help marketers to design strategies to serve consumers effectively. This model can also be applied to other fashion associated products and other consumer goods. Likewise, consumers can be classified based on their motives to buy these products. This model can be applicable to other disciplines such as HR, Finance, Operations etc. Distinct clusters obtained by dividing consumers on different characteristics can help strategist to design effective strategy in different sectors.

\subsection{Limitations:}

Utmost care was taken to collect genuine responses however respondent's bias cannot be neglected. Also, researcher has used non probability judgement sampling method to collect responses. Results may not be applicable to outside world. This study has been done for urban consumers who are using personal care products on daily basis. Other criteria's such as usage frequency, buying frequency, expenditure on personal care products can give better insights.

\subsection{Scope for further Research:}

This research can be used for other functional areas such as HR, Finance where consumer behavior study can be done to segment consumers into different clusters to serve them best, thus,maximizing good consumer experience while consuming particular service. 
DOI: 10.14807/ijmp.v12i5.1413

This study is useful for fashion industry, make-up industry, male consumer grooming, fragrance market, cosmetic market to design strategies and create profitable niche market for effective customer serving and better customer relationship management.

\section{REFERENCES}

Ahaiwe, E. O. (2015). Analysis of Determinants of Brand Preference for Cosmetics in Abia State, Nigeria. The International Journal Of Business \& Management, 3(9), 244-250.

Anandarajan, T. S. (2016). Consumer Purchase Decision Behaviour Towards. Asia Pacific Journal of Research, 1(37), 144-149.

Bassi, F. (2014). Forecasting financial products acquisition via dynamic segmentation An application to the Italian market. International Journal of Market Research, 57(6), 909932.

Bee L., \& Yeo, R. (2016). A Study of Malaysian Consumer Purchase Motivation of halal cosmetics retail products : Examining Theory of Consumption value and customer satisfaction. ScienceDirect, 37, 176-182.

Branko R. Maričić. (2015). Strategic Market Segmentation. Marketing, 46, 243- 251.

Ciobanu, E. K. (2014). Exploring the role of Country of Origin for Luxury Personal Care Products in India. NMIMS Management Review, 115-130.

Constantin, C. (2012). Post-Hoc Segmentation Using Marketing Research. Annals of the University of Petroşani. Economics, 12(3), 39-48.

Infante, V. H. P. (2016). Cosmetics consumption behaviour among men and women and the importance in products indication and treatment adherence. Surg Cosmet Dermatol, 8(2), 231-241.

Jain, V. (2014). Exploring the role of Country of Origin for Luxury Personal Care.

Junaid, A. B. (2013). Behaviour of Indian Consumer towards Skin Care roducts

(Cosmeceuticals) -Conceptual Model. International Journal Of Advanced Research, 512518.

Kamyar Kianpour, R. A. (2014). Important Motivators for Buying Green Products.

Important Motivators for Buying Green Products, 10(5), 873-896.

Kim, J.-E. C. (2011). Consumer purchase intention for organic personal care products.

Journal of Consumer Marketing, 28(1), 40-47.

Madeira, A. B. (2015). Marketing Segmentation: Your Role For Diversity in Dynamical Systems. Revista Gestão.Org., 13(1) ,71-78.

Marija Cerjak, Ž. M. (2010). What Motivates Consumers to Buy Organic Food: Comparison of Croatia, Bosnia Herzegovina, and Slovenia. Journal of Food Products Marketing, 16(3), 278-292.

Matić, M. (2016). Consumers' Purchase Intentions Towards Natural Cosmetics. ECONVIEWS, 29(1), 53-64.

Nadai, M. I. (2015). The lipstick effect and the self-enhancement motives. Economies and finances, $1-56$.

Pezúa, O. R. (2016). Influence of Non-Economic Factors in the Use of Personal Care 
DOI: 10.14807/ijmp.v12i5.1413

Products: The Case of Male Peruvian Consumer. Universidad \& Empresa. 18(31), 121-138.

Samar Fatima, S. L. (2015). Impact of Advertisement on Buying Behaviours of the consumers: Study of Cosmetic Industry in Karachi City. International Journal of Management Sciences and Business Research, 4(10), 125-136.

SueLin, T. C. (2010). UNDERSTANDING consumer purchase behaviour in japanese personal Grooming Sector. Journal of Yasar University, 17(5), 2911-2921.

Sukato, D. B. (2009). A Model Of Male Consumer Behaviour In Buying Skin Care Products In Thailand. ABAC Journal, 29(1), 39-52.

Sultan, M. M. (2013). Buying Motives of Herbal Skin Care Products: Study on Dhaka city Consumers. International Review of Business Research Papers, 9(5), 68-80.

Thakkar, D. (2017). Factors influencing buying behaviour of men’s towards grooming products. International Journal of Multidisciplinary Research and Development, 4(8), 242-248.

Tan, Y. O. C-E. (2018). Conceptual Study on Malaysian Male Consumption Behaviour Towards Skin Care Products. International Journal of Innovation and Business Strategy (IJIBS), 9(1), 1-12.

Vaishali, K. (2013). Cosmeceuticals An Emerging Concept: A Comprehensive Review. International Journal Of Research In Pharmacy And Chemistry, 3(2), 308-316.

Varsha Jain, E. K. (2014). Exploring the role of Country of Origin for Luxury Personal Care.

Vibhuti, D. r. (2014). A Case Study on Consumer Buying Behavior towards Selected FMCG Products. International Journal Of Scientific Research And Maangement, 2(8), 11681182. 